\title{
Immunohistochemical Characterization of Lymphocytic CD3/CD20 and Macrophage CD68 in the Germinal Epithelium of Pb and Se+Zn Treated Adult Sprague-Dawley Rats
}

\section{Falana $\mathrm{BA}^{1,2}$, Ogundele $\mathrm{OM}^{3 *}$, Duru $\mathrm{FI}^{2}$, Osinubi $\mathrm{AA}^{2}$ and Falode $\mathrm{DT}^{4}$}

${ }^{1}$ Department of Anatomy, Faculty of Basic Medical Sciences, Osun State University, Osogbo, Nigeria

${ }^{2}$ Department of Anatomy, College of Medicine, University of Lagos, Lagos Sate, Nigeria

${ }^{3}$ Department of Anatomy, College of Medicine and Health Sciences, Afe Babalola University, Ado-Ekiti, Nigeria

${ }^{4}$ Department of Nursing, College of Medicine and Health Sciences, Afe Babalola University, Ado-Ekiti, Nigeria

\begin{abstract}
Lead toxicity in the testes has been described to be capable of inducing cell death by apoptosis and necrosis. Such toxicity can be attenuated by selenium and zinc synergy treatment in trace amount. This study evaluates the role and distribution of macrophages/histocytes (CD68), B-Lymphocytes (CD20) and T-Lymphocytes (CD3) in the testes of lead, selenium and zinc treated rats.
\end{abstract}

60 F1 generation adult male Sprague-Dawley rats were divided into four groups of 15 animals each. Group 1 received normal saline, group 2: $100 \mathrm{mg} / \mathrm{Kg}$ of lead acetate, group 3: $100 \mathrm{mg} / \mathrm{kg}$ of lead acetate then $2.25 \mathrm{mg} /$ $\mathrm{Kg}$ each of Zinc (Chelated zinc) and Selenium (Sodium Selenium) and group 4: $2.25 \mathrm{mg} / \mathrm{kg}$ of zinc and selenium $(\mathrm{Se}+\mathrm{Zn})$. The duration of treatment was 56 days following which the animals were sacrificed on the $57^{\text {th }}$ day and the testes harvested and fixed in Bouin's fluid.

CD3, CD20 and CD68 are distributed within the epithelium and the interstitium of the Pb treated testis, the expression level is influenced by the extent of the damage posed by $\mathrm{Pb}$ toxicity and not by the proliferative tendencies of $\mathrm{Se}+\mathrm{Zn}$ treatment did protect the germinal epithelium and the macrophage/lymphocyte cell lines.

Keywords: Selenium; Zinc; Lead; Cell death; Germinal epithelium; Macrophages; B-lymphocytes; T-lymphocytes

Abbreviations: Pb: lead; Se: Selenium; Zn: Zinc; Se+Zn: Selenium and Zinc co-treatment; $\mathrm{Pb}+\mathrm{Se}+\mathrm{Zn}$ : Lead, selenium and Zinc cotreatment

\section{Introduction}

A major feature of the germinal epithelium is its orientation and highly specific arrangement involving sophisticated molecular interaction and coordination at cellular and membrane level [1]. The "germinal epithelium" describes the interior of the seminiferous tubules in anatomical corona and sagittal section that exposes the lumen and the tail of the spermatozoa [2]. The floor of the epithelium is formed by a basement membrane composed of specialize matrix and adhesive proteins some of the molecules of which are highly charged and forms the ionic barrier. Resting on this membrane is the base of the giant multi-projected sustenacular cells of the Sertoli [3]. Together the base of the Sertoli cells and the adjoining basement membrane interacts with series of junctional complexes especially desmosomes and hemidesmosomes while adjacent Sertoli cells communicate by chemical signals through the gap functions [4-6].

The importance of the barrier cannot be over elucidated considering the delicate nature of the cells of the spermatogenic linage lining the walls of the grooves created by the multi projected cytoplasmic processes of the Sertoli cells [7]. Other cell present includes the Leydig's cell (which produces steroids) [8]. Structural evidence support the ideology of a barrier but certain wandering cells of the blood always pass via diapedesis into the epithelium and interstitial spaces to promote immunogenic support and protection of the germinal epithelium [9]. Some of these cells includes macrophages (CD68), T-lymphocytes (CD3+) and B-lymphocytes (CD-20+) [10-12]. In case of lead $(\mathrm{Pb})$ toxicity, two separate pathways have been identified to be capable of inducing cell death via necrosis and apoptosis; representing events that will activate macrophage (CD68) and lymphocytic response systems (CD3 and CD20). The objective of this study is to assess the expression of CD3, CD20 and CD68 in Pb toxicity in the testes of adult Sprague-Dawley Rats; where $\mathrm{Pb}$ was used to induce toxicity and Selenium (Se) and Zinc (Zn) synergy was used to attenuate such toxic effect. CD20 is an activated, glycosylated phosphoprotein expressed as a surface antigen in all B-cells beginning from the pro-B phase (Effector B-cells; CD45+) and increases in population till full maturity, even up till plasma cells [13].

In the Human species, the gene encoding for CD20 plays an important role in the development of B-cells into plasma cells which involves conversion of most of the metabolic machinery into antibody production (can produce antibodies at a very rapid rate of 2,000 molecules per minute) $[14,15]$. The presence of CD20 on tissue sections represents B-cell neoplasm and its absence in such times might be an indication of T-lymphocyte (CD3) infiltration into tissue sites [16,17]. $\mathrm{CD} 3$ is a protein complex consisting of 4-subchain and characteristic of cluster of differentiation in T-lymphocytes [18], it has been found to be expressed in the cytoplasm if pro-thymocytes (undifferentiated

*Corresponding author: Ogundele OM, Department of Anatomy, College of Medicine and Health Sciences, Afe Babalola University, Ado-Ekiti, Nigeria, E-mail: ola.ogundele@abuad.edu.ng

Received February 28, 2013; Accepted April 02, 2013; Published April 05, 2013

Citation: Falana BA, Ogundele OM, Duru FI, Osinubi AA, Falode DT (2013) Immunohistochemical Characterization of Lymphocytic CD3/CD20 and Macrophage CD68 in the Germinal Epithelium of $\mathrm{Pb}$ and $\mathrm{Se}+\mathrm{Zn}$ Treated Adult Sprague-Dawley Rats. J Cytol Histol 4: 171. doi:10.4172/2157-7099.1000171

Copyright: (c) 2013 Falana BA, et al. This is an open-access article distributed under the terms of the Creative Commons Attribution License, which permits unrestricted use, distribution, and reproduction in any medium, provided the original author and source are credited. 
Citation: Falana BA, Ogundele OM, Duru FI, Osinubi AA, Falode DT (2013) Immunohistochemical Characterization of Lymphocytic CD3/CD20 and Macrophage CD68 in the Germinal Epithelium of Pb and Se+Zn Treated Adult Sprague-Dawley Rats. J Cytol Histol 4: 171. doi:10.4172/21577099.1000171

lymphocytes) that invades inflammatory tissue sites or under stress such as that observed in $\mathrm{Pb}$ toxicity; they normally function to destroy infections and malfunctioning cells and their number might increase as a form of first line immune reaction before the activation of B-cells (CD20) [19]. CD68 is characteristic of macrophages which are seen to infest tissue sites and remove cell debris and infections [20,21]. CD20, CD3 and CD68 were immunohistochmeically labelled to described lymphocytes activation and distribution in $\mathrm{Pb}$ toxicity and in $\mathrm{Se}+\mathrm{Zn}$ treatment following $\mathrm{Pb}$ toxicity.

\section{Methods}

60 F1 generation adult Sprague-Dawley rats were used. The animals were procured and kept in the animal holding facility of the Osun State University and allowed to acclimatize. The animals were then divided into 4 groups of 15 animals each. The animal handling protocol followed the Helsinki Convention on animals use for research and was approved by the Animal Use in Research Committee of the Osun State University. Group 1 (control) received normal saline, group 2 received $100 \mathrm{mg} / \mathrm{Kg} \mathrm{BW}$ of lead acetate $(\mathrm{Pb})$, group 3 received $100 \mathrm{mg} / \mathrm{Kg}$ of $\mathrm{Pb}$, $2.25 \mathrm{mg} / \mathrm{Kg}$ of Se and $2.25 \mathrm{mg} / \mathrm{Kg}$ of $\mathrm{Zn}$. The duration of treatment was 56 days for all groups. The animals were sacrificed on the $57^{\text {th }}$ day and the testes were dissected to obtain the seminiferous tubule. The tissues were immediately fixed in Bouin's fluid (histology) and Formolcalcium (Immunohistochemistry) for 24 hours; the tissues for histology were transferred into a change of Bouin's fluid for another 24 hours. Tissue processing was done to obtain paraffin wax embedded sections using the method of [22] (Se: Sodium Selenium and Zn: Chelated Zinc).

\section{Histology}

The embedded tissues were sectioned to obtain $7 \mu \mathrm{m}$ thick sections for routine histological staining in Hematoxylin and Eosin $(\mathrm{H}$ and $\mathrm{E})$ using the method of [23].

\section{Immunohistochemistry}

The paraffin wax embedded sections were mounted on a glass

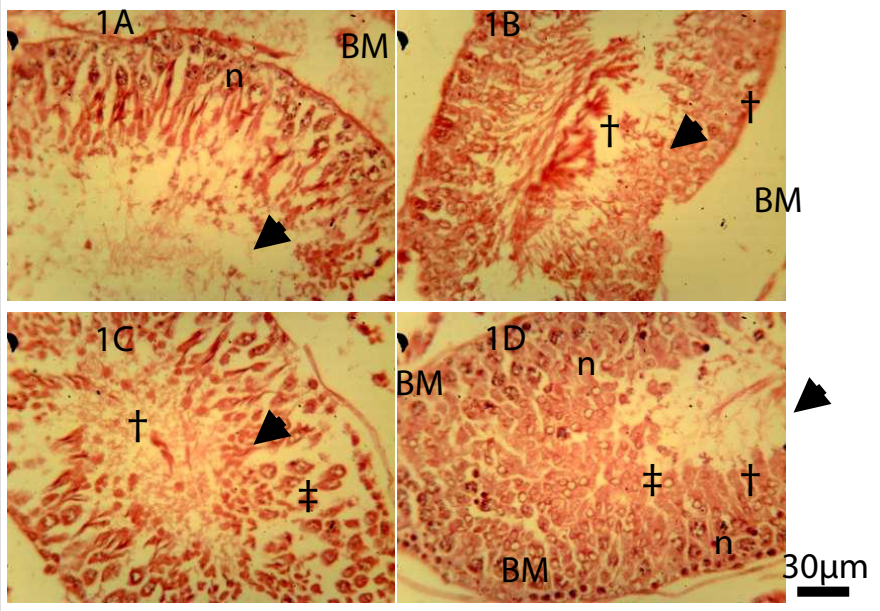

Figure 1: General Morphology of the germinal epithelium of wild type adult Sprague-Dawley rats (stained with Hematoxylin and Eosin). (A) Contro (B) $100 \mathrm{mg} / \mathrm{Kg} \mathrm{Pb}$-Acetate (C) $\mathrm{Pb}-$ Acetate+Se+Zn and (D) Se+Zn only Degeneration was most prominent in the lead treatment group; cell proliferation is most prominent in the $\mathrm{Sn}+\mathrm{Zn}$ treatment group. $(\ddagger)$ represents regions of cell proliferation and $(t)$ represents regions of cellular degeneration, $(n)$ represents normal cells of the epithelium, (BM) basement membrane, arrow head indicates the lumen of the seminiferous tubule (Scale bar is $30 \mu \mathrm{m}$ ).

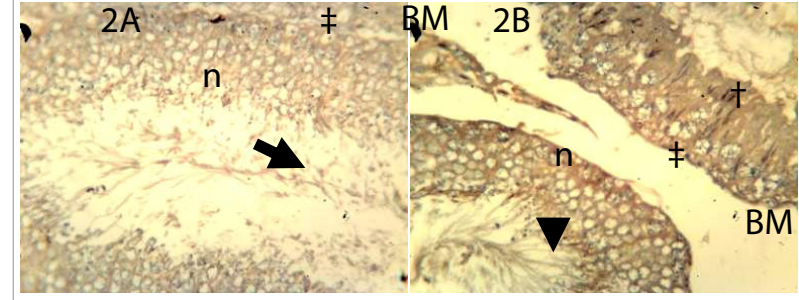

$2 \mathrm{C}$

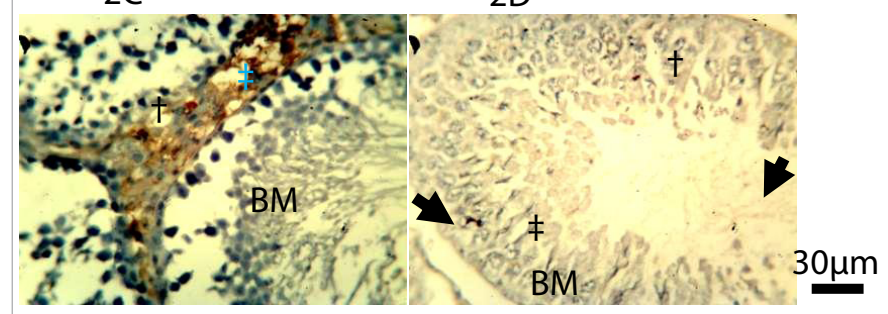

Figure 2: $C D 68+$ immunohistochemistry in the germinal epithelium of wild type adult Sprague-Dawley rats. (A) Control (B) $100 \mathrm{mg} / \mathrm{Kg}$ Pb-Acetate (C) $\mathrm{Pb}-\mathrm{Acetate}+\mathrm{Se}+\mathrm{Zn}$ and (D) $\mathrm{Se}+\mathrm{Zn}$ only. CD68 activity is higher around the BM of the epithelium where the cell population is basically composed of spermatogonia and the sustenacular cells of Sertoli; $(\ddagger)$ represents regions of CD68 immunopositivity and $(\dagger)$ represents regions of cellular degeneration, $(n)$ represents normal cells of the epithelium, (BM) basement membrane, arrow head indicates the lumen of the seminiferous tubule (Scale bar is $30 \mu \mathrm{m}$ ).

slide in preparation for antigen retrieval. The slides were immersed in urea overnight and then placed in a microwave for 45 minutes to re-activate the antigens and proteins in the tissue sections. Primary antibody treatment involved treating the sections with biotinylated goat serum for one hour following which the sections were transferred to $1 \%$ bovine serum albumin (BSA) to block non-specific protein reactions. Secondary treatment involved the use of diluted anti-CD3, Anti-CD20 and Anti-CD68 on the pre-treated sections for one hour. The immunopositive reactions were developed using a polymer 3'3' Diaminobenzidine Tetrachloride (DAB) with colour intensification involving the use of mathenamine silver kit. The sections were counterstained in Hematoxylin and treated in $1 \%$ acid alcohol (freshly prepared)

\section{Transformation}

Methenamine silver intensification was used on the immunoperoxidase preparation after the peroxidase $/ \mathrm{H}_{2} \mathrm{O}_{2} / \mathrm{DAB}$ reaction has been carried out to give a brown deposit. The sections were then counterstained in Hematoxylin. The counterstained sections were washed in running tap water, thoroughly rinsed in distilled water, and placed in preheated methenamine silver solution at $60^{\circ} \mathrm{C}$ for five minutes. Although it could be occasionally longer if the intensification had been carried out at room temperature. In this study, to further increase the clarity, Hematoxylin was removed from counterstained nuclei with $1 \%$ acid alcohol before the silver intensification was carried out. The composition of the stock solution was $0.125 \%$ silver nitrate in $1.5 \%$ hexamine. The solution was stored at $4^{\circ} \mathrm{C}$. Prior to use, $2 \mathrm{ml}$ of $5 \%$ tetraborate was added to $50 \mathrm{ml}$ of the stock silver solution giving a $\mathrm{pH}$ of 8.0, which was then filtered into a coupling jar and protected from sunlight.

\section{Results and Discussion}

The highest immunopositivity was observed in the $\mathrm{Pb}$ treatment only (Figure $2 \mathrm{~B}$ ) and the $\mathrm{Pb}$ treatment followed by $\mathrm{Se}+\mathrm{Zn}$ trace treatment 
Citation: Falana BA, Ogundele OM, Duru FI, Osinubi AA, Falode DT (2013) Immunohistochemical Characterization of Lymphocytic CD3/CD20 and Macrophage CD68 in the Germinal Epithelium of Pb and Se+Zn Treated Adult Sprague-Dawley Rats. J Cytol Histol 4: 171. doi:10.4172/21577099.1000171

(Figure 2C). In the control and $\mathrm{Pb}$ treated group the activities of CD68 was not restricted to any specific region but widespread across necrotic or apoptotic tissues sites (Figure $2 \mathrm{~A}$ and $2 \mathrm{~B}$ ). The CD68 activity was predominant in the basement membrane of the $\mathrm{Pb}+\mathrm{Se}+\mathrm{Zn}$ treatment (Figure 1C and 2C), the control was only slightly immunopositive (Figure 2A) showing very few restricted sites close to the basement membrane. This implies the presence of macrophages (CD68) could be restricted to stress response or damage rather than being present all the time (Figure 2A); this was again re-confirmed in group 4 (Figure 2D), treated with trace $\mathrm{Se}+\mathrm{Zn}$, the region showed increased cell population but was only immunopositive at restricted sites similar to the control. Distribution of B-cells is important in the cytology of the testes under the toxicity response model as macrophages and mast cells will stimulate a complement system recruiting B-lymphocytes for specific immunogenic response. The activities of B-cells (CD20) was higher in the basement membrane of the control (Figure 1A and 3A) and the basement membrane of the $\mathrm{Pb}+\mathrm{Se}+\mathrm{Zn}$ treatment (Figure $1 \mathrm{C}$ and $3 \mathrm{C}$ ), while immunopositive reactions were restricted to the tissue sites close to the lumen in the degenerating tissue (epithelium) of $\mathrm{Pb}$ treatment and diffused the basement membrane region of $\mathrm{Se}+\mathrm{Zn}$ treatment group 4 (Figure 1D and 3D).

Immunohistochemical localization of undifferentiated lymphocytes shows that, the CD3+ activities were merely localized around the basement membrane and spaces between adjoining seminiferous tubules. The presence of this category of cells increased in the $\mathrm{Pb}$ treatment group (Figure $1 \mathrm{~B}$ and $4 \mathrm{~B}$ ) within the epithelium and was restricted to the basement membrane region in the control group (Figure 4A). Some level of immunopositivity was observed in the lumen of the $\mathrm{Pb}+\mathrm{Se}+\mathrm{Zn}$ (Figure $4 \mathrm{C}$ ) as well as the basement membrane, while higher immunopositivity was observed in the $\mathrm{Se}+\mathrm{Zn}$ treatment group (Figure 4D). The studies of Duan et al. [24] suggest that infection and inflammation in the epithelium is an important etiologic factor responsible for male infertility, other results indicates that T-lymphocytes are involved in the regulation of pathogenesis involved in male infertility [25]. In their study they characterized
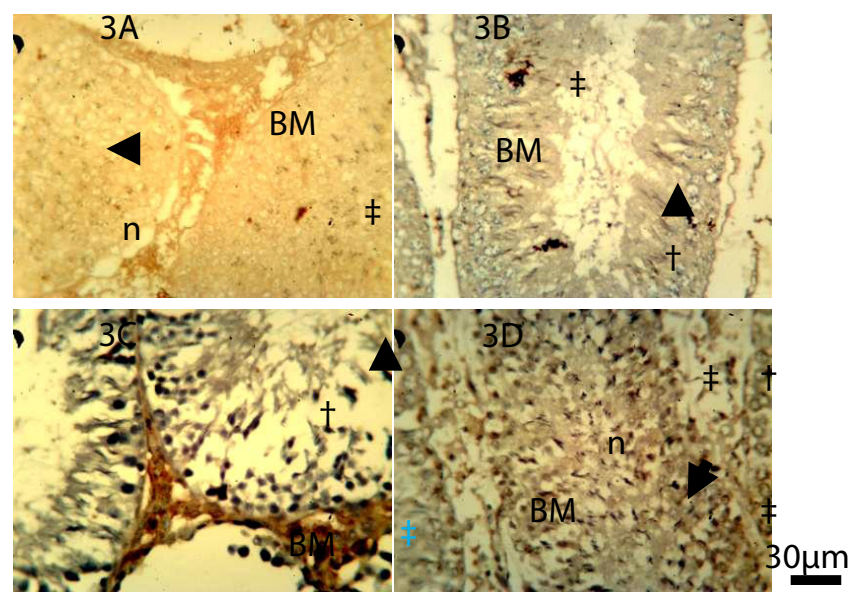

Figure 3: $C D 20+$ immunohistochemistry in the germinal epithelium of wild type adult Sprague-Dawley rats. (A) Control (B) $100 \mathrm{mg} / \mathrm{Kg} \mathrm{Pb}$-Acetate (C) PbAcetate $+\mathrm{Sn}+\mathrm{Zn}$ and (D) Se+Zn only. CD20+ activity is higher around the BM and the Sertoli cell region of the epithelium where $(\ddagger)$ represents regions of CD68 immunopositivity and $(\dagger)$ represents regions of cellular degeneration, $(n)$ represents normal cells of the epithelium, (BM) basement membrane, arrow head indicates the lumen of the seminiferous tubule. Se+Zn (3D) showed a widely diffused $\mathrm{CD} 20+$ reaction (Scale bar is $30 \mu \mathrm{m}$ ).

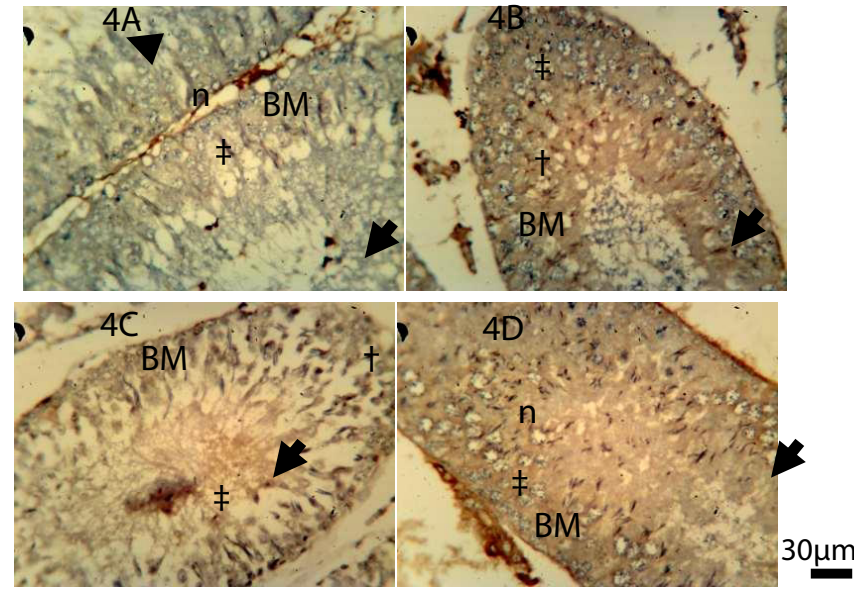

Figure 4: $C D 3+$ immunohistochemistry (for undifferentiated lymphocytes) in the germinal epithelium of wild type adult Sprague-Dawley rats. (A) Contro (B) $100 \mathrm{mg} / \mathrm{Kg} \mathrm{Pb}$-Acetate (C) Pb-Acetate+Se+Zn and (D) Se+Zn only. CD3+ activity is high in the $\mathrm{BM}$ of the $\mathrm{Pb}$ treatment $(4 \mathrm{~B})$, in the $\mathrm{BM}$ and degenerating cells of the lead treated group (4B), in the $\mathrm{BM}$ of $\mathrm{Pb}+\mathrm{Se}+\mathrm{Zn}$ and it is widely diffused in the epithelial cells of the $\mathrm{Se}+\mathrm{Zn}$ treated group (4C and $5 \mathrm{D}$ ). ( $f$ ) represents regions of $C D 3+$ immunopositivity and $(\dagger)$ represents regions of cellular degeneration, $(n)$ represents normal cells of the epithelium, (BM) basement membrane, arrow head indicates the lumen of the seminiferous tubule (Scale bar is $30 \mu \mathrm{m}$ ).

immune response infiltration using monoclonal antibodies for B-, T- lymphocytes and CD68 for macrophages, [25] histologically and immunologically confirmed the presence these cells in the interstitium, tubular walls and lumen of the testes, and the findings were further elucidated using morphometric analysis techniques. This is similar to our findings although the present study uses CD3+ for T-lymphocyte and CD20+ for B-lymphocytes.

Marchelwicz described the ultra structure and immunohistochemistry of human epididymis (CD3, CD20, CD45 and CD68), lymphocytes and macrophages were observed closed to the basement membrane mixed within the epithelial cells, while immunohistochemical reaction for $\mathrm{CD} 3+$ and $\mathrm{CD} 68$ were positive around the interstitial tissue [11]. This study further confirms that in lead toxicity such activity might extend from the interstitial spaces into the interior of the basement membrane close to the region of cell death and necrotic tissue sites. Extranodal CD20 are often seen in cases of peripheral T-cell lymphomas, autopsy of degenerating or lymphoma testicular tissue reveals positivity for CD3 and CD20. Transient CD20 expression is an important diagnostic marker clinically to characterize cell disorder, death and inflammation in the testes [26,27]. Certain lymphomas and disease conditions also lack CD20 expression [28] an example is the plasmablastic lymphomas and associated conditions.

Our study also confirms that the macrophage (CD68) and the lymphocyte cells lines are non-responsive to the Se and $\mathrm{Zn}$ treatment, although $\mathrm{Se}+\mathrm{Zn}$ did protect the cells of the germinal epithelium, comparing the treatment with the control. This was also proposed by [29], who used Selenium and genistein and found the Se and genistein synergy was protective against the adverse effect of anticancer drugs; also [30], 2012 describes the protective effect of Se in cadmium toxicity in chicken splenic lymphocytes. Certain doses of Zinc have been found to be protective against infections [31]. It was observed that zinc can activate the adaptive immune system; this was investigated by the 
Citation: Falana BA, Ogundele OM, Duru FI, Osinubi AA, Falode DT (2013) Immunohistochemical Characterization of Lymphocytic CD3/CD20 and Macrophage CD68 in the Germinal Epithelium of Pb and Se+Zn Treated Adult Sprague-Dawley Rats. J Cytol Histol 4: 171. doi:10.4172/21577099.1000171

expression of B-lymphocytes and T-lymphocytic surface antigens. Zinc has also been found to be capable of mediating apoptosis in degenerating cells to prevent tumorgenesis in the testicular cells [32], thus the role of $\mathrm{Zn}+\mathrm{Se}$ can be described as protective to the testicular epithelium and lymphocytic system but possesses less activation effects for lymphocytes in the control and $\mathrm{Pb}$ treated groups. These metals have also been found to maintain cell order by destroying tumorgenic cells and thus preventing cancer. $\mathrm{Se}+\mathrm{Zn}$ deficiency extent of the damage generate several auto immune deficiencies.

\section{Conclusion}

CD3, CD20 and CD68 are distributed within the epithelium and the interstitium of the $\mathrm{Pb}$ treated testis, the expression level is influenced by the extent of the damage posed by $\mathrm{Pb}$ toxicity and not by the proliferative tendencies of $\mathrm{Se}+\mathrm{Zn}$ treatment did protect the germinal epithelium and the macrophage/lymphocyte cell lines.

\section{Acknowledgement}

Special thanks to the ETF desk Officer, Osun State University, Asubairo Osogbo Nigeria. We acknowledge the contributions of Jonathan Madukwe of the Histopathology Department, National Hospital Abuja, Also the Directorate of Research, Afe Babalola University, Ado-Ekiti, Nigeria. Conflict of Interest (COI) Statement: The Authors hereby declare there is no conflict of interest associated with this study or any of the procedures and materials used for the purpose of the study.

\section{References}

1. Almasiova V, Holovska K, Tarabova L, Cigankova V, Lukacinova A, et al. (2012) Structural and ultrastructural study of the rabbit testes exposed to carbamate insecticide. J Environ Sci Health A Tox Hazard Subst Environ Eng 47: 13191328.

2. Krockova J, Massányi P, Toman R, Danko J, Roychoudhury S (2012) In vivo and in vitro effect of bendiocarb on rabbit testicular structure and spermatozoa motility. J Environ Sci Health A Tox Hazard Subst Environ Eng 47: 1301-1311.

3. Tousson E, El-Moghazy M, Massoud A, Akel A (2012) Histopathological and immunohistochemical changes in the testes of rabbits after injection with the growth promoter boldenone. Reprod Sci 19: 253-259.

4. Mok KW, Lie PP, Mruk DD, Mannu J, Mathur PP, et al. (2012) The apica ectoplasmic specialization-blood-testis barrier functional axis is a novel target for male contraception. Adv Exp Med Biol 763: 334-355.

5. Sakr SA, Mahran HA, Nofal AE (2011) Effect of selenium on carbimazoleinduced testicular damage and oxidative stress in albino rats. J Trace Elem Med Biol 25: 59-66.

6. Zhang WD, Wang WH, Xu XH, Zhaxi YP, Zhang LJ, et al. (2012) The histological characteristics of the aggregated lymphoid nodules area in abomasum of Bactrian camels (Camelus bactrianus) of different ages. Vet Immunol Immunopathol 147: 147-153.

7. Su W, Liu X (2013) Rab13 regulates Sertoli cell permeability barrier dynamics through protein kinase A. J Mol Endocrinol .

8. Noguchi J, Nakai M, Kikuchi K, Kaneko H, Imaeda N (2013) Early Regression of Spermatogenesis in Boars of an Inbred Duroc Strain Caused by Incident Orchitis/Epididymo-orchitis. J Reprod Dev

9. Takashima S, Kanatsu-Shinohara M, Tanaka T, Takehashi M, Morimoto H, et al. (2011) Rac mediates mouse spermatogonial stem cell homing to germline niches by regulating transmigration through the blood-testis barrier. Cell Stem Cell 9: 463-475.

10. Turner TT, Tung KS, Tomomasa H, Wilson LW (1997) Acute testicular ischemia results in germ cell-specific apoptosis in the rat. Biol Reprod 57: 1267-1274.

11. Marchlewicz M (2001) Localization of immunocompetent cells in the human epididymis. Folia Histochem Cytobiol 39: 173-174.

12. Pérez-Vallés A, Sabater-Marco V, Carpio-Máñez $D$, Botella-Estrada $R$ Nogueira-Vásquez E, et al. (2000) Extranodal peripheral T-cell lymphoma with angiocentric growth pattern and Epstein-Barr viral DNA associated affecting paratesticular soft tissue. J Cutan Pathol 27: 80-86.
13. Mendes DS, Dantas ML, Gomes JM, dos Santos WL, Silva AQ, et al. (2013) Inflammation in disseminated lesions: an analysis of CD4+, CD20+, CD68+ $\mathrm{CD} 31+$ and $\mathrm{vW}+$ cells in non-ulcerated lesions of disseminated leishmaniasis. Mem Inst Oswaldo Cruz 108: 18-22.

14. Rafiq S, Butchar JP, Cheney C, Mo X, Trotta R, et al. (2013). Comparative Assessment of Clinically Utilized CD20-Directed Antibodies in Chronic Lymphocytic Leukemia Cells Reveals Divergent NK Cell, Monocyte, and Macrophage Properties. J Immunol 190: 2702-2711.

15. Danielou-Lazareth A, Henry G, Geromin D, Khaznadar Z, Briere J, et al. (2013) At diagnosis, diffuse large B-cell lymphoma patients show impaired rituximabmediated NK-cell cytotoxicity. Eur J Immunol .

16. DiLillo DJ, Yanaba K, Tedder TF (2010) B cells are required for optimal CD4+ and CD8+ T cell tumor immunity: therapeutic B cell depletion enhances B16 melanoma growth in mice. J Immunol 184: 4006-4016.

17. Gadri Z, Kukulansky T, Bar-Or E, Haimovich J, Hollander N (2009) Synergistic effect of dendritic cell vaccination and anti-CD20 antibody treatment in the therapy of murine lymphoma. J Immunother 32: 333-340.

18. Sudzius G, Mieliauskaite D, Butrimiene I, Siaurys A, Mackiewicz Z, et al. (2013) Activity of T-helper cells in patients with primary Sjogren's syndrome. In Vivo 27: $263-268$

19. Schürch C, Riether C, Amrein MA, Ochsenbein AF (2013) Cytotoxic T cells induce proliferation of chronic myeloid leukemia stem cells by secreting interferon-y. J Exp Med 210: 605-621.

20. Heller DS (2012) CD68 immunostaining in the evaluation of chronic histiocytic intervillositis. Arch Pathol Lab Med 136: 657-659.

21. Abreu-VelezAM, Howard MS, Hashimoto K, Hashimoto T (2009) Autoantibodies to sweat glands detected by different methods in serum and in tissue from patients affected by a new variant of endemic pemphigus foliaceus. Arch Dermatol Res 301: 711-718.

22. Jeong CW, Kim H, Kim S, Kim SH, Moon C, et al. (2007) Immunohistochemical study of flotillin-1 in rat testis with ischemia/reperfusion injury. Cell Biol Int 31 : 609-614.

23. Karenma, Babij R, Cortés E, Vonsattel JP, Louis ED (2012). Cerebella pathology of a dual clinical diagnosis: patients with essential tremor and dystonia. Tremor Other Hyperkinet Mov (N Y). 2012;2. doi:pii: tre-02-107-6707. Epub 2012 Aug 6.

24. Duan YG, Yu CF, Novak N, Bieber T, Zhu CH, et al. (2011) Immunodeviation towards a Th17 immune response associated with testicular damage in azoospermic men. Int J Androl 34: e536-e545.

25. Hussein MR, Abou-Deif ES, Bedaiwy MA, Said TM, Mustafa MG, et al. (2005) Phenotypic characterization of the immune and mast cell infiltrates in the human testis shows normal and abnormal spermatogenesis. Fertil Steril 83 1447-1453.

26. Makita M, Murakami I, Yoshioka T, Tanaka H, Yamamoto K, et al. (2009) Extranodal CD20-positive peripheral T-cell lymphoma presenting with adrenal and testicular masses. Rinsho Ketsueki 50: 413-418.

27. Jones C, St-Jean S, Fréchette I, Bergeron D, Rivard N, et al. (2012) Identification of a novel promyelocytic leukemia zinc-finger isoform required for colorecta cancer cell growth and survival. Int J Cancer.

28. Armitage JO (2012) My treatment approach to patients with diffuse large B-cell lymphoma. Mayo Clin Proc 87: 161-171.

29. Sonaa E, Usha S, Ja In J (2013) An ex vivo study of selenium, genistein on the morphological and nuclear changes in anticancer drug-induced apoptosis in human peripheral blood lymphocytes. Biofactors .

30. Chen X, Zhu YH, Cheng XY, Zhang ZW, Xu SW (2012) The protection of selenium against cadmium-induced cytotoxicity via the heat shock protein pathway in chicken splenic lymphocytes. Molecules 17: 14565-14572.

31. Janczyk P, Kreuzer S, Assmus J, Nöckler K, Brockmann GA (2013) High dosage of dietary zinc oxide has no protective effects on weaned pigs infected with Salmonella enterica serovar Typhimurium DT 104. Appl Environ Microbiol

32. Wysokinski D, Blasiak J, Wozniak K (2012) Zinc differentially modulates DNA damage induced by anthracyclines in normal and cancer cells. Exp Oncol 34: 327-331. 